\title{
The Anxiety as a Trigger of the Repressive Actions in the Novel Still Alice
}

\author{
Anik Widya Wati \\ Balikpapan University \\ aprilawidya@gmail.com \\ Rosmiati \\ Balikpapan University \\ rosmiati@uniba-bpn.ac.id \\ Waladdin Panggabean \\ Balikpapan University \\ waladdin@uniba-bpn.ac.id
}

\begin{abstract}
:
This research focuses on the anxiety of Alice Howland in the novel Still Alice by Lisa Genova. There are two objectives of this research, they are; to find out the kinds of anxiety on Alice Howland and to explain the condition of anxiety as a trigger of the repressive actions to Alice Howland. The research uses Psychoanalysis theory by Sigmund Freud which talks about anxiety and defense mechanism. The methodology employed is qualitative in which the researcher presents the issues descriptively and uses the data collected from the novel. The result shows the kinds of anxiety that happens to Alice Howland, namely hormonal anxiety, social anxiety and attack anxiety which could trigger the repressive actions. The researcher also finds several repressive actions in Still Alice, namely repetition, moral felling and composing self.
\end{abstract}

Keywords: psychoanalysis, anxiety, repressive actions, defense mechanism, still Alice

\section{INTRODUCTION}

In this study, the researcher chooses the novel Still Alice which tells of a lecturer who has a personality problem that is anxiety or excessive anxiety due to Alzheimer's disease which makes his daily activities disrupted which triggers self-defense actions in the form of repressive action. The novel is a story about Alice Howland, a well-known professor of 
linguistics at Columbia University who has anxiety after she was diagnosed with Alzheimer's disease. The main character struggles to get rid of her anxiety by taking repressive actions or relieving anxiety such as when her illness recurs where she has to do teaching activities on campus she takes notes to help her remember every activity she will do. Howland does this to reduce her anxiety due to the mistakes she made after being diagnosed by Alzheimer. As stated by Sigmund Freud:

"An important distinction between a more primary automatic anxiety, triggered by a traumatic situation in which the helpless ego is overwhelmed and signal anxiety, which can be activated in the ego response to situations of danger as a kind of warning that a traumatic situation is imminent, so that defensive measures can be put into place to avoid it." (Freud Sigmund, 2006).

In this study the researcher concludes that anxiety is an automatic and is triggered by a traumatic situation where the ego is helpless so that the anxiety signal is activated in the ego's response to danger situations as a kind of warning that a traumatic situation is imminent, so that defensive actions can be taken to avoid it. This 'dangerous situation' tends to skew around threats that arise from the prospect of being helpless and at the mercy of others: the threat of losing a loved one, losing someone else's love, or being attacked. In the end, Freud claimed, this threat was a manifestation of a more fundamental threat. Actually there are three types of anxiety according to Freud, namely neurotic anxiety, moral anxiety, and realistic anxiety. Neurotic anxiety is anxiety that arises without knowing the dangers that threaten it. This anxiety can be sourced from its unconscious. Moral anxiety comes from the conflict between the ego (the principle of reality) and the superego (moral and ideal conditions). This moral anxiety can occur when a child feels failed to live the moral principles he holds. This realistic anxiety is anxiety that is closely related to fear. This anxiety is defined as an unpleasant feeling, an unspecified feeling involving the possibility of danger. In this novel the anxiety experienced by the character Alice Howland triggers the precautions that she takes in the form of Repressive Actions..

Repression can sometimes be mistaken for suppression. Unlike repression, suppression is when a person consciously forces unwanted thoughts, memories, or feelings out of conscious awareness. As stated by Sigmund Freud:

"The repression kind of unconscious is the third level and is referred to as the unconscious mind. This part of physic deals with unconscious repress data. It is reservoir of the feeling, thought, urges, and memories that are outside of our conscious awareness" (Freud,1949)

In this study the researchers concludes that if someone experiences excessive anxiety or anxiety then tends to be repressive by looking for ideas, thoughts or ideas in order to overcome anxiety felt outside of his consciousness. Repression can also be interpreted as individual actions to reduce the excessive anxiety felt as contained in this study the researchers found several repressive actions carried out by the character to reduce his anxiety with the ideas he created, one of which was by making notes in each activity so that he did not forget what he would do that day. 
In this novel, anxiety is very influential for the character of Alice Howland. The researcher is interested in examining the problems in Still Alice using Sigmund Freud's Psychoanalytic theory of Personality Dynamic discussion of Anxiety and Sigmund Freud's theory of Ego's Defense Mechanism.

Based on the background of the problem before the researcher have the opinion that the anxiety that occurs in Alice Howland in the novel also occurs in the real reality of several events related to excessive anxiety resulting in the actions of each individual's self-defense measures to protect themselves and reduce the excessive anxiety that able to interfere with the psychiatric sufferers of anxiety. Anxiety can occur due to several factors such as: trauma of a thing or the past, a relationship with the environment that is not good so that they feel excessive anxiety, plus the lack of attention from people around with excessive anxiety on someone who can threaten the mentality of the person, or have a disease that dangerous so that sufferers will continue to experience anxiety about fear of death and a feeling of self-distrust again. Anxiety like this is difficult to eliminate and from eighty percent of cases Anxiety is still widely experienced by humans due to several factors that have been discussed previously, especially this anxiety is in every any individual is just different levels of anxiety. To reduce excessive feelings of anxiety can be done by giving motivation to sufferers of excessive anxiety in order to be more confident and think positively to themselves that every human being has anxiety but can be reduced by having more positive thinking.

\section{LITERATURE REVIEW}

This study uses a literary psychology approach found in humans using the basis of Sigmund Freud's Psychoanalysis, which explains the anxiety or excessive anxiety that occurs in each individual. The researcher also explain how anxiety can trigger repressive action or how the individual's brain reduces feelings of anxiety as a result of the three anxiety above so that the individual is able to suppress their anxiety.

\section{Worry/Anxiety}

Anxiety is an important variable of almost all personality theories. Anxiety as a result of the conflict which is an inevitable part of life, is seen as a major component of personality dynamics.According to Sigmund Freud in the Calvin Hall's book, Freud said that:

"Anxiety is feeling of impending danger. It warn the ego to do something to prevent the danger from doing harm superego. considered three types of anxiety which are reality anxiety, neurotic anxiety and moral anxiety". (in Hall, Calvin, S.1954)

As an important part of Freud's theory or belief, he also appreciated the thoughts that were fundamental to neuritis and psychotic development. For example, as found in the character of Alice Howland in the novel Still Alice where Howland experienced excessive anxiety caused by Alzheimer's disease which she suffered caused her to lose normal brain function. 


\section{Repression}

Repression can carry out memories of situations and people, as well as our perception of the present (so it is very likely that we will fail to see situations that are clearly disturbing events), even to bodily functions. Once a repression is carried out, it is very difficult to eliminate it. As Sigmund said,

"The repression kind of unconscious is the third level and is referred to as the unconscious mind. This part of physic deals with unconscious repress data. It is reservoir of the feeling, thought, urges, and memories that are outside of our conscious awareness" (Freud in Siegfried, 2014 p.2).

Based on the above quotation, the researcher concludes that repressive is an action, idea of thought or an individual's way of reducing or reducing feelings of anxiety so that the anxiety that an individual feels does not interfere with the activities that are being carried out because excessive anxiety will usually cause things that interfere with the activities of the individual. In some cases, anxiety is a trigger for repressive action which makes a person tend to look for ways to reduce the anxiety that is being felt.

For an example, in the novel Still Alice the character Alice Howland tried to control the anxiety that she had due to being overly anxious about her illness by taking excessive selfprotective actions, one of them is by making notes and placing them in every corner of the house because she was too anxious about brain function disorders she suffers.

\section{RESEARCH METHODOLOGY}

In this research the methodology used by researcher is a qualitative descriptions method. To facilitate the researcher, the researcher uses the method so that the data will be collected according to the classification using description word. Qualitative methods can provide a means to develop a context-rich description and understanding of phenomena. Qualitative methods are particularly appropriate when the researcher wants to gain a deeper understanding of a known phenomenon or desires to develop knowledge or theory in a new area.

The researcher uses qualitative research methods in order to develop a description and understanding of the phenomenon under study with paragraphs so that it is easy to understand. Qualitative methods are appropriate methods when researcher want to gain a clearer understanding of a known phenomenon or desire to develop knowledge based on the object under study or to develop explanations for theories used in new fields.

To collect the data, the researcher conducts some steps. First, the researcher reads the selected novel. The first reading is done to know the story. Then, the researcher identifies the problem of the main character. To make sure about the problem, the researcher repeated the reading process again.

After reading processes have been done, the researcher begins to identify the part which shows the problem and effects of anxiety which is depicted by Alice Howland. The types of 
anxiety as a trigger of defense mechanism which is repressive actions used by the main character for reducing her anxiety are becoming the object that the researcher would like to find in this novel.

After that the researcher read some books which are related to the topic of the novel. The researcher also finds more information about the novel and the theory from internet by reading journals and articles. Besides, the researcher takes data from the novel and secondary data that relevance to the topic.

\section{FINDINGS}

\section{Kinds of Anxiety depicted by Alice Howland}

The types of anxiety that the researcher found with Alice Howland were realistic anxiety, moral anxiety and neurotic anxiety, in which this anxiety greatly interfered with Alice's activities causing her to experience several stresses.

\section{Realistic Anxiety}

The first kind of anxiety is realistic anxiety which is an unpleasant feeling and is not specific which includes the possible harm itself. Realistic anxiety is the fear of real dangers emanating from the outside world such as natural disasters or threats from other people.

\section{Moral Anxiety}

The second kind of anxiety is moral anxiety that stems from the conflict between the ego and the superego. This anxiety can arise from failure to be consistent with what they believe is morally right. Moral anxiety is fear of conscience. Moral anxiety also has its basis in reality, in the past the person has been punished for violating moral norms and can be punished again.

\section{Neurotic Anxiety}

The third kind of anxiety is neurotic anxiety that happens due to unknown dangers. The feeling resides in the ego but arises from the drive of the id. Neurotic anxiety is not fear of the instincts themselves but fear of punishment that might result if an instinct is satisfied.

\section{Kinds of Anxiety as a Trigger for Repressive Actions depicted by Alice Howland}

In this study the researcher found three repressive actions by Alice Howland due to her anxiety, namely the first 4 repetitions of each of the anxiety she felt and the second 7 moral feelings of each anxiety and the third 6 self-composing actions. of each anxiety that Alice Howland feels. As a result of feeling so great anxiety, it eventually triggers repressive attitudes in Alice Howland to help her to calm down. 


\section{DISCUSSION}

\section{Kinds of Anxiety depicted by Alice Howland}

The kinds of types of anxiety that the researchers found in Alice Howland's character were hormonal anxiety, social anxiety and attack anxiety, which made Howland always feel paranoid and scared.

\section{Hormonal Anxiety}

The first in this study the researcher found some excerpts that consist of anxiety. The first kind of anxiety depicted by Alice Howland is Hormonal Anxiety, according to Sigmund Feud, hormonal anxiety is Some areas of hormonal changes that can create anxiety include estrogen dominance, pregnancy, and thyroid dysfunction Estrogen dominance is often associated with perimenopause or PMS, causing surging hormones and a challenge to control emotions during this time. Alice Howland had been anxious since she was diagnosed with her Alzheimer. She was anxious because she because she was worried after knowing that she had forgotten pretty badly.

"What do you think is going on? Is this just normal forgetting? I Told him my story, and i couldn't remember John Black's address." She look at him directly in the eye. A colleague of hers had one told her that eye contact with another person for more than six seconds withing looking away or blinking revealed a desire for either sex or murder". (Lisa Genova, 2014. p.64)

The above quote mentions the part when Dr. David tested Alice Howland, in just a few minutes the doctor asks Howland the same question and apparently she forgets. Dr. David begins to realize that things are not true in Howland's memory, which makes it easier for her to forget things like a simple set of questions she was asked a few minutes prior. Dr. David asked Howland to come back in a few weeks to see if there is a change that would likely to occur in Alice's memory. This begins to make Alice Howland becomes anxious, something as simple as that turned out to be easily forgotten by her. Alice feels this is not only because she is old enough but forgets that she feels different from the forgetfulness experienced by older people. Based on Sigmund Freud's theory of anxiety, the above excerpt is an example of anxiety's realistic feature where Alice feels an unpleasant and unspecified anxiety, including feeling the possibility of danger itself. Realistic anxiety is the fear of real dangers emanating from the outside world.

\section{Social Anxiety}

The second kind of anxiety depicted by Alice Howland is social anxiety. According to Sigmund Feud, social anxiety is people with social anxiety has everyday social interactions cause irrational anxiety, fear, self-consciousness and embarrassment.. Alice Howland has been anxious since she was diagnosed with her Alzheimer. She was anxious she is worried after knowing that she has been forgotten things pretty badly.

"I forget words. I completely forgot the topic of the lecture I was supposed to give in the time it took to walk from my office to class, I can't decipher the 
intention behind words I write in the morning on my to do list by the middle of the afternoon". (Lisa Genova, 2014 p.90)

The above quote is proven when Alice told her husband John that she is worried because of her forgetfulness that she will not be able to carry out her responsibilities as a lecturer, because in the past few days prior to the conversation, when she was teaching in her class, Alice Howland forgot her own sentences and it made her feel guilty and ashamed. The incident keeps repeating until it makes her students confused.

Based on Freud's theory, this kind of anxiety is a type of moral anxiety where Howland feels anxious because of the superego's feeling of guilt. It feels guilty for not being able to complete the teaching responsibility due to her forgetfulness appearing ever so suddenly in the middle of her teaching.

\section{Attack Anxiety}

The third kind of anxiety depicted by Alice Howland is attack anxiety. According to Sigmund Feud, attack anxiety is usually involves a fear of some specific occurrence or problem that could happen. Alice Howland has been anxious since she was diagnosed with her Alzheimer.

"Well, Dad, are you happy? I've got your lousy DNA. You're going on get to kill us all. How does it feel to murder your entire family?". Her crying, Explosive and anguished, would have seemed appropriate to any stranger observing the scene-her dead parents and sister buried in the ground, the darkening graveyard, the eerie beech tree". (Lisa Genova, 2014 p.87)

The quote above shows when Alice feels anxious about her past with her father and mother and sister who have long since died. Alice is annoyed at the thought that she has inherited Alzheimer's DNA which is why she must have experienced things that have gone wrong, namely a severe disease of forgetfulness. Alice Howland, who realizes that her transformation has become corrupted, grows even stronger when she recalls having this history of forgetfulness when she was a child. She often sees important things that can interfere with current activities and diseases that come upon her.

According to Freud, these things include neurotic anxiety in which the main character is very anxious when remembering the illness she experiences. When she comes to her family members' grave, she cries in front of the graves. She feels it is appropriate to kill her slowly with this disease because ever since the doctor diagnosed herself as having severe forgetfulness she feels now that she can only cry in her husband's arms. This is Alice's way of relieving her anxiety. By crying she can take a little bit of burden and worry about the DNA of this forgetful disease which might pass on to her children.

\section{Repressive Actions depicted by Alice Howland}

\section{Repetition}

The first In this study the researcher found some excerpts that consist of anxiety as a trigger of repressive actions depicted by Alice Howland. The first the realistic anxiety as trigger 
repressive actions according to Sigmund Feud, The repression kind of unconscious is the third level and is referred to as the unconscious mind. This part of physic deals with unconscious repress data. It is reservoir of the feeling,thought, urges, and memories that are outside of our conscious awareness.

The first excerpt found by the researcher in the novel describe Alice Howland's anxiety realistic as a trigger of repressive actions when she when she first felt a severe forgetfulness.

"what do you think is going on? is this just normal forgetting.? I Told him my story, and i couldn't remember John Black's address. She look ed him directly in the eye. A colleague of hers had one told her that eye contact with another person for more than six seconds withing looking away or blinking revealed a desire for either sex or murder. (Lisa Genova, 2014 p.64)

According to Sigmund, Alice's action was her brain's way of looking trying to calm down in order to reduce the anxiety she experiences because she feels as if she is in danger.

\section{Moral Feeling}

When Alice tells her husband John that she is worried because of her forgetfulness, she feels embarrassed. Anxiety helps Alice in the end to act repressively. She reduces her anxiety by writing down every word she would speak in the morning before starting to teach and taking notes again in the afternoon.

"I forget words. I completely forgot the topic of the lecture I was supposed to give in the time it took to walk from my office to class, I can't decipher the intention behind words I write in the morning on my to do list by the middle of the afternoon. (Lisa Genova, 2014 p.90)

Based on this, it can be seen from Freud's theory that Alice can reduce her anxiety based on her sense of the moral responsibility to her students because her brain refers to ways of making repressive actions such as making notes before going to campus.

\section{Self-Composure}

When remembering her past with her father and mother and sister who had long died, Alice feels resentful to her father because her father had given her the Alzheimer's DNA. Alice feels that her father had made her life a mess. Alice's anxiety grew stronger when she remembers the father did have a history of this forgetfulness when Alice was a child. Alice often saw her father forget important things that could interfere with her father's activities at the time and this illness is passed down to her.

"Well, Dad, are you happy? I've got your lousy DNA. You're going on get to kill us all. How does it feel to murder your entire family?". Her crying, Explosive and anguished, would have seemed appropriate to any stranger observing the scene-her dead parents and sister buried in the ground, the darkening graveyard, the eerie beech tree". (Lisa Genova, 2014 p.87) 
Prologue: Journal on Language and Literature Vol.6 No.2 (2020)

According to Freud, such things include neurotic anxiety in which Alice is anxious when recalling the illness that she had experienced to her father when she was a child. Crying in front of her father's grave is a form of self-composure to repress her anxiety.

\section{CONCLUSION}

After analyzing anxiety depicted by Alice Howland in the novel Still Alice, the researcher can concludes the types of anxiety illustrated by Alice Howland. Here, Alice Howland as the object of the research experiences some forms of anxiety. Those are realistic anxiety, moral anxiety and neurotic anxiety.

The realistic anxiety is shown by when Alice Howland met Dr. David to ask whether it was easy to forget this was normal, but what Dr. David said was that it was not normal even if Alice had Alzheimer's disease. Her anxiety caused by her feeling of guilt for not being able to carry out her responsibilities properly, is an example of moral anxiety where an individual feels anxious due to feelings of guilt or moral shame to her environment for not being able to carry out duties properly. Neurotic anxiety is shown when Alice is anxious when she recalls the time of her childhood and reminisces about things that have been experienced in the past such as trauma so that it creates a feeling of anxiety or worries that really disrupts activities.

The researcher also finds source the how the anxiety as a trigger of repressive actions. Based on the psychoanalysis theory, the anxiety occurs because there are biology as represented by the id, reality as represented by superego and the center of the powerful process as represented by ego when there is conflicting demands upon the poor ego, feel overwhelmed, feel threatened this is feeling is anxiety.

Meanwhile, the question is related to how anxiety triggers repressive actions by Alice Howland as the main character of analysis based on psychoanalytic theory, namely the first realistic anxiety, where Alice Howland becomes afraid and worries when she finds out that she has Alzheimer and she knows the trigger for her repressive actions. Based on the psychoanalysis theory, namely the first realistic anxiety, where Alice is so afraid and worried when she finds out that she has Alzheimer and her anxiety increases when she also finds out that this disease has a great potential to pass on to her children. Furthermore, the second is moral anxiety, where Alice always feels anxiety and guilty of moral responsibility to her work because ever since she experienced Alzheimer in doing her job she is always disturbed even when teaching in front of the class several times she has to be silent because she forgot what to say and the third is neurotic anxiety, which is Alice's anxiety which comes when she remembers several times of her childhood where her father also has the same disease DNA as her now, all of these worries eventually trigger repressive actions on Alice to reduce the anxiety she always feels even she can't sleep every night because of the anxiety that always bothered her. The repressive actions that Alice takes are always taking notes before doing activities, especially notes for class teaching materials, taking sedatives and vitamins, calming herself down by means of every anxiety occurrence Alice closes her 
eyes and takes deep breaths or speaks with her imagination and reassures herself. itself because all of these things can reduce the anxiety that happens to her.

\section{References}

Abrams, M. (1999). A Glossary of Literature Terms. Autralia,Canada,Mexico, and United Kingdom States: Heible \& Heinle.

Bertens, K. (1979). Memperkenalkan Psikoanalisa. Jakarta: PT. Gramedia.

Creswell, J. (2013). Five approach and theory qualitative reserach methods. Retrieved from https://brightkite.com/essay-on/qualitative-research-methods-j-w-creswell: https://brightkite.com/essay-on/qualitative-research-methods-j-w-creswell

Denzim, N. (1994). Handbook of Qualitative Research. Yogyakarta: Pustaka Pelajar.

Esten, M. (1989). Menjelang Teori Sastra yang Relevan. Bandung: Angkasa.

Freud, S. (1949). Memperkenalkan Psikoanalisis. Jakarta: Gramedia.

Freud, S. (2006). Pengantar Umum Psikoanalisis. Yogyakarta: Pustaka Belajar.

Hall, C. S. (1954) Pengantar Ke Dalam Ilmu Jiwa Sigmund Freud. Jakarta-New York: Yayasan Penerbit Franklin.

Genova, L. (2014). Still Alice. Jakarta: Gramedia.

Pervin, L. C. (2010). Psikologi Kepribadian: Teori dan Penelitian. Jakarta: Kencana.

Pratami, A. V. (2016). the research is the conflicts of the main character in the novel entitled still Alice by Lisa Genova. Depok: Universitas Gunadarma.

Tiwouw, M. P. (2017). A Research The Anxiety of main character to make decision in the novel IF I Stay by Gayle Forman. Balikpapan: Universitas Balikpapan.

Walgito, B. (2004). Pengantar Psikologi Umum. Yogyakarta: Andi Offiset. 